\title{
Analysis on the Human Resource Management of Private Colleges and Universities from the Strategic Point of View
}

\author{
Jiaqing Wang \\ Yunnan Normal University, Business School, Yunnan, China
}

\begin{abstract}
With the progress of educational reform, the allocation of university teachers has gradually changed, and private university human resources management as an important part of educational development, shouldering the dual protection role of teaching and management. With the popularization of higher education, opportunities and challenges both exist for colleges and universities. How to optimize the human resource management and provide the most comprehensive and scientific reserve force for the development of colleges and universities is the main task of human resources management.
\end{abstract}

Keywords: human resource management in private colleges and universities, education; resource allocation

\section{Introduction}

Private colleges and public schools have the fundamental difference is that private colleges and universities have a profit line, need to self-financing, college teachers' salaries, benefits and so on by the university's profitability to decide a year. With the popularization of higher education in China, many college teachers have welcomed many opportunities and started to improve their salary and environment. At the same time, under the circumstance of many colleges and universities, the competition is fierce, so they face a lot of problems. In order to better realize the healthy development of private colleges and universities, to strengthen the standardization of management and support for the human 
resources management of colleges and universities, can effectively promote the development of education.

\section{Basic concepts of human resources in private colleges and universities}

Private colleges and universities and public universities is a relative concept, public universities belong to the state institutions and organizations funded, for the community to organize higher education schools and institutions, and private colleges and universities with the reform and opening up, by private or non state investment Appropriation of private education collectively. With the development of private colleges and universities has become the main base for the implementation of higher education in China, of which China's issued by the National Development and Reform Commission of the State Council, the Ministry of Education of the People's Republic of China, "The development of private colleges and universities in China after 30 years of development, has formed a university with Chinese characteristics, the development model, in the education sector, the development of private institutions of higher learning, Occupy an unparalleled role. Compared with the public universities, the development of private colleges and universities has the type of housing, autonomy in school activities, internal management and the allocation of funds and other public universities do not have the flexibility. Especially in the age of competition for education knowledge competition, the competition between universities is becoming fierce. Many private colleges and universities in the human resources management as a result of various factors resulting in the staffing is not complete, different levels and other aspects of private universities The quality of education has caused serious impact, and gradually restricted the development of private universities.

\section{The current situation of human resources management in private colleges}

Since the reform and opening up, the ranks of private universities in China has been growing, human resources management is more responsible because of the composition, so the management more difficult, and large private college staff mobility, many teachers in the structure of the problem, plus school training Keep up with the other aspects of the reasons leading to the development of many colleges and universities are limited factors, the following we have for the University of the main problems of analysis.

The first is the composition of human resources in colleges and universities are more complex, so that a unified management more difficult. Many colleges and universities to adopt a flexible mechanism for management, so long the complexity of the composition of personnel, many teachers in the part-time, full- 
time teachers, and many are some college graduates, part-time teachers are mostly Public college retired teachers, so to achieve a unified management is more complex. At the same time for the logistics of personnel in colleges and universities are more diversified, college graduates, corporate retirees and college staff and other family members and other staff. So also created a management can not be unified.

Because of the small social identity of private colleges and universities, and limited personal growth and room for growth, coupled with the salary is not very high, so many people are more popular, resulting in limited development of colleges and universities. According to the survey found that many college parttime teachers in addition to most of the retired public colleges and universities faculty in addition to the efficient read Master, Ph.D. and more, the problem is generally to earn extra money, once necessary or have a better job, Will resign, so this can be a long private college mobility of a larger factor.

As the nature of private colleges and universities determine the age of teachers under the age of 30, and more than 60 teachers, and teachers in the early and midlevel staff more, and fewer senior officers, resulting in the backbone of teachers in colleges and universities, lack of management personnel, University teachers with irrational power.

As the funding source of non-state-run colleges and universities is not the state funding, all operations mainly to tuition-based, university decision-makers is the investor, in addition to the purpose of education, but also has a certain profitability. Therefore, the existing private universities are relatively similar in scale, low operating costs, many colleges and universities as a result of school resource constraints, resulting in the neglect of human resources management, and further the lack of respect for teachers on campus and cultivate talent atmosphere, leading to Development of Private Colleges and Universities is Restricted.

For the teacher's training is not enough, resulting in the overall quality of teachers is not high. Human resources itself is the need to spend energy, financial and human resources to vigorously develop, and now many colleges and universities tend to focus only on personnel, do not attach importance to the cultivation of talent. The other is the heavy task of teaching teachers themselves, so do not have much energy to do further improvement, so that the overall quality of teaching can not be improved. Thirdly, due to the difference between the colleges and universities and the higher mobility of personnel, many colleges and universities tend to pay attention to the immediate interests, do not want to spend time and money to do the training and development of human resources.

Another point is the lack of scientific performance appraisal system, resulting in a lot of college management there is a big problem. Which performance evaluation and management are all performance appraisal system inside. At present, many colleges and universities are based on the school situation established performance evaluation methods, according to the survey, these evaluation methods are basically subjective, there are a lot of weight unreasonable for teachers can not play the role of incentives. The other is a lot of evaluation according to the methods and standards for the evaluation of different 
evaluation system lack of coherence and there is no analysis of the evaluation and feedback. At the same time, universities only pay attention to the assessment process, but can not correctly face the main problems of human resource management.

\section{Challenges of human resources management in universities and colleges from a strategic perspective}

First of all, with the development of the knowledge-based economy market, the higher the demand for knowledgeable talents is, the better the training of highquality talents is. It is the main manifestation of the best human resources management of human resources management in colleges and universities. Configuration can quickly enhance the comprehensive competitiveness of colleges and universities to strengthen the overall level of high-level education.

In addition, with the continuous development of market economy, the competition among universities is also increasingly fierce. Therefore, in order to better promote the healthy development of colleges and universities, it must be equipped with scientific concept and model of human resources management, through scientific assessment and sound management by encouraging staff to develop personal development plans to promote and improve the faculty all aspects of knowledge and skills, to achieve healthy and stable development of colleges and universities.

From the strategic point of view, how to realize the optimal allocation of resources in the human resources management of the private colleges and universities need to use the resources of the society at the same time, and at the same time, constantly strengthen the teaching experience and the introduction of management technology, through the integration of resources, so efficient use, to meet the needs of private universities and the community to enhance the overall competition.

In order to better meet the challenge of social human resources management, colleges and universities should fully integrate their own characteristics and effective human resource allocation, and constantly improve the school's development strategy, the university's differentiation of the human resources management of private universities from the strategic point of view to find a more suitable for the development of the school's innovative management concepts, to better meet the current needs of social development. At the same time, in order to better the internal development trend of private colleges and universities, the human resources management concept should be people-oriented, the spirit of incentives and material incentives, through the integration and use of human resources colleges and universities to enhance the overall strength of colleges and universities. 


\section{The Strategy of Strengthening Human Resource Management in Private Colleges and Universities}

In order to solve the main problems in the current human resources management, it is necessary to improve the management of the institutions of higher learning in order to better solve the main problems in the current human resources management of private colleges and universities. Therefore, Personnel for human resources have a new understanding, attention to human resources management in the development of colleges and universities.

First of all, managers should establish and improve the mechanism of college personnel selection and promotion, through the allocation of talents with the establishment of a high-quality, professional teachers and management personnel. Since the beginning of the staff's initial campaign, should pay attention to the introduction of high-level talent, private universities because of their flexible employment mechanism, so for high-level talent, especially highly educated, high-title talent in treatment can give a certain Attention, to create a good working environment, to ease the instability of talent. At the same time in the talent selection to take full account of the talent selection criteria and postevaluation methods, selection of personnel to meet the job requirements. In addition to note that the talent selection, there must be a certain title, job promotion mechanism, so that they have the opportunity to have the ability to achieve their career goals, so as to achieve the reserves of private college teachers.

In addition for private universities, is itself a self-financing form of education, so the raising of funds is an important factor in the development of colleges and universities. Private colleges and universities can use a more flexible mechanism, the use of the advantages of the school itself, and enterprises to cooperate, through the establishment of school-enterprise joint and other means to encourage teachers to participate in scientific research and production experience, training double teacher. At the same time, the school can also develop a variety of sources of funding through the "to promote research", "to research and production", thus increasing human resources investment. In order to better retain talent, pay level is particularly important to improve the method, colleges and universities only enough teachers, in order to better development.

The third is the optimization of teachers, reduce the loss of talent. In private universities, the loss of high-quality talents is the biggest human resource cost. If the personnel structure is not perfect, then the teaching level will not be improved, and the talent cultivation is unknown. In order to better solve this problem, in addition to scientific and perfect selection, promotion mechanism, there is a good working environment, a good working environment allows teachers to be due respect, enrich their business culture, capital, increase The school's sense of belonging and sense of responsibility, through gradual progress, college personnel structure can be resolved, the quality of teaching can also be improved.

Fourth, a set of scientific and perfect performance appraisal system, can fully mobilize the enthusiasm of the work. In the work through the performance evaluation for teaching quality and school management problems, to facilitate the faculty to work more responsibly, on the other hand can encourage teachers to 
actively participate in on-the-job teaching training and schools [7], Improve the level of teaching, but also through various measures to enable young teachers to adapt to the needs of teaching and job. At the same time in the evaluation, the need for adequate assessment of the object to consider and reduce the impact of subjective factors, so that the work of fair and impartial evaluation.

\section{Conclusion}

Human resources management of private colleges and universities is related to the development goals and strategies, a sound and scientific human resources management can help solve the problem of college students, as well as social competition. From a strategic point of view, human resources management is the core of university development, which involves the allocation of teacher resources, as well as the establishment of management mechanisms. This paper analyzes the current problems of the university human resources management and summarizes the main strategies to solve the problems. It expounds the direction of the development of universities and the development of universities can not do without the support of the state and the management of colleges and universities. We should develop a sound human resources management system, scientific talent selection mechanism, pay attention to personnel training, create a good teaching environment and promote the development of private colleges and universities.

\section{References}

[1] Li Haimei. Discussing the Management Path of Human Resources Development in Private Colleges Based on the Innovation Mechanism, 55(12), pp.68-70, 2011

[2] Cao Wenxiu. Discussion on the Construction of Teaching Staff in Non governmental Institutions of Higher Learning on the Basis of Strategic Human Resource Management, Journal of Chifeng University, 8 (5), pp.87- 91, 2013

[3] Hu Yan. Research on the Coping Modes of Human Resource Management in Private Colleges - Based on Maslow's Demand Hierarchy Theory. Contemporary Economy, 12(10), pp. 18- 20, 2012

[4] Zhou Huichao, Zhou Huizhe. Preliminary Study on Problems and Countermeasures of Human Resources Management in Private Universities. Science \& Technology Information, 9(6), pp.58- 61, 2011

[5] Shi Yuanbo. Study on Human Resource Management of Non-governmental Institutions of Higher Learning from the Perspective of Knowledge Management.

China Management Informationization, 8(4), pp.85-87, 2014 